\title{
Organic farming - a challenge to nutritionists
}

\author{
K. Jakobsen ${ }^{1}$ and J.E. Hermansen ${ }^{2}$ \\ 'Department of Animal Nutrition and Physiology \\ 2Department of Agricultural Systems \\ Danish Institute of Agricultural Sciences, \\ Research Centre Foulum \\ P.O. Box 50, DK-8830 Tjele
}

\begin{abstract}
This paper is a position paper summarising the state of research within organic animal production in Denmark with emphasis on cattle, pigs and poultry. The goal of $100 \%$ organic feed in 2005 within EU for organic farmstock requires a high level of self-supply. Cereals and straw are limited. Forage and roughage must be part of the daily feed. The ban on GMOs, synthetic amino acids and vitamins, organic solvents, medicinal substances and early weaning reduces the number of alternatives. Research is highly needed: 1 . To cstablish the requirements and supply of energy, essential amino acids, vitamins and minerals under organic farming conditions with slow-growing breeds, 2. To develop feeding concepts in order to improve the resistance to infectious diseases of the gastrointestinal tract, 3 . To improve product quality and production cconomy. The challenge to nutritionists is to solve these problems in a way compatible with the holistic idea of organic farming and farm life.
\end{abstract}

KEY WORDS: cattle, pigs, poultry, roughage, vitamins, amino acids

\section{INTRODUCTION}

During the last decade there has been a rapid development and a great increase in the area of organic farming and in organic animal production both in Europe (Foster and Lampkin, 1999) and the rest of the world. This development is due to an increased market because of an increased interest in society for sustainable agriculture.

Organic production aims at a better environment and more healthy animal husbandry than is practised in to-day's conventional farming systems. It considers environment and nature, conservation of the countryside, biological diversity, animal welfare, inherent product quality and consumer health and welfare. It aims at solving these problems from a holistic point of view. 
Livestock production forms an integral part of many organic farms. Livestock production must contribute to the equilibrium of agricultural production systems by providing the nutrient requirements of crops and by improving the soil's organic matter. It can thus help establish and maintain soil-plant, plant-animal and animal-soil interdependence.

The organic production method must meet the basic standards of the "International Federation of Organic Agricultural Movements" (IFOAM, 2000). Within EU it must also meet the rules laid down in Council Regulation (EC) No 1804/ 1999 of 19 July 1999 supplementing Regulation (EEC) No 2092/91 on organic production of agricultural products and indications referring thereto on agricultural products and foodstuffs to include livestock production. Furthermore, member states of EU may apply stricter rules to livestock and livestock products produced within their territory. The term for organic production and products differs within EU. In English the term is organic, but in Danish, Swedish and Spanish it is ecological, in German ecological or biological, and in French, Italian, Dutch and Portuguese it is biological (EEC Regulation No 2092/91).

The whole idea behind organic living, the set of standards and rules laid down to accomplish organic production place many restrictions on animal production. The present paper will focus mainly on the problems and challenges organic production provides as to the nutrition of cattle, pigs and poultry. Emphasis will be on the research going on in Denmark to provide the knowledge necessary to obtain a sustainable nutrition of organically produced farm animals.

\section{DEMANDS ON FEED}

These are laid down in Council Regulation (EC) No 1804/1999, Annex I, § 4. Some of the main rules and their consequences are reviewed in the following.

- Feed is intended to ensure quality production rather than maximising production, while meeting the nutritional requirements of the livestock at various stages of their development. Thus, a balanced high-quality diet is required.

- Livestock must be fed on organically produced feedingstuffs preferably from the farm itself. A limited proportion of conventional feedingstuffs is permitted within a transitional period expiring on 24 August 2005.

- The feeding of young mammals must be based on natural milk, preferably maternal milk for a minimum period depending on the species.

- Rearing systems for herbivores are to be based on maximum use of pasturage according to the availability of pastures in the different periods of the year. At least $60 \%$ of the dry matter in daily rations is to consist of roughage, fresh or dried fodder, or silage unless nationally a permission for a reduction to $50 \%$ for animals in dairy production for a maximum period of three months in early lactation has been given. 
- Roughage, fresh or dried fodder, or silage must be added to the daily ration for pigs and poultry, and for poultry in the fattening period at least $65 \%$ of the feed formula must contain cereals.

- Only feed materials listed in Annex II of Council Regulation No. 1804/1999 whether conventional or organically produced can be used (a positive list). Furthermore, conventional feed materials of agricultural origin can be used only if they are produced or prepared without the use of chemical solvents. This implies, that e.g. soyabean meal, the most common protein source in animal nutrition, cannot be used in organic feeds.

- Antibiotics, coccidiostats, medicinal substances, growth promoters or any other substance intended to stimulate growth or production shall not be used in animal feeding.

- No feed components may have been produced with the use of genetically modified organisms (GMOs) or GMO derivatives.

- Vitamins authorised for conventional animal production under Directive 70/524/ EEC must preferably be derived from raw materials occurring naturally in feedingstuffs or synthetic vitamins identical to natural vitamins only for monogastric animals.

In Denmark stricter rules have been laid down by the authorised body the Plant Directorate under the Ministry of Food, Agriculture, and Fisheries in "Administrative Order on Amendment of Order on Organic Farming". But also private bodies may impose stricter rules as e.g. by the dairy co-operation Arla Food, which gives premium prices if the production is based on entirely organic feeds, and by some smaller dairies which only accept milk from cows fed $100 \%$ organic feed.

Overall, however, the challenges for research within nutrition can be summarised as mainly:

- Inclusion of roughage, fresh or dried fodder or silage in the diet of pigs and poultry. To what extent are these ingredients utilised and do they affect product quality?

- Exclusion of chemically - synthesised or GMO derived amino acids and vitamins.

How to satisfy the requirements of amino acids without feeding excessive amounts of nitrogen? How to supply the animals with adequate levels of vitamins?

- To feed the animals without the use of antibiotics, coccidiostats and growth promoting agents.

How to develop new feeding concepts which may prevent impairment of health? How is production economy influenced?

In fact some of these items have become part of the feeding strategy of conventional farming, and many of the aspects of research may also be relevant for conventional food production. 


\section{RESEARCH PRIORITIES AND FACILITIES IN DK}

Promoting organic farming has been part of Danish government policy for several years. The Danish Research Centre of Organic Farming (DARCOF) was established in 1996 with the purpose of co-ordinating and promoting research in organic farming. DARCOF is a "centre without walls" actually a network coordinating research activities of 15 institutes, around 100 scientists and 40-50 ongoing projects. Among other objectives the centre must ensure that the research system focusses on the most relevant challenges within the development of organic farming and the promotion of sustainability in agriculture as a whole. Furthermore, the Danish Government has actively supported the conversion of agriculture into organic farming and invested about 120 million DKK (15 million EURO) into research in organic farming in the period 1996-2000. Following the conclusion of the second Danish Action Plan for organic farming in 1999 a new major research initiative 'DARCOF-II' was initiated. This initiative, which has a total value of 227 million DKK ( 28 million EURO) consists so far of 26 major research projects including projects related to feed resources and nutrition of farm animals (DARCOF, 2001).

To support the research in organic livestock production appropriate research facilities are needed. The Danish approach in relation to research in organic animal nutrition comprehends classical experimental stables including facilities for digestibility trials and metabolic measurements.

However, in order to facilitate new research topics of special interest in organic livestock production, a new organic experimental station was established in 1996. The overall idea was to create an experimental unit in which feeding experiments and nutrition studies, among other things, could be carried out with pigs and cattle kept under free range conditions, managed organically and fed organically produced feed.

The research station «Rugballegård» comprehends 140 ha with a stock of 60 cows and 60 sows including the corresponding young animals. Three different crop rotations were established representing the relevant rotation for a pig, a dairy and a combined pig and dairy production, respectively. The facilities for nutrition studies in pigs include:

- a range of different pens for slaughter pigs with access to an outdoor run (Møller and Olsen, 1998) in which roughage can be fed,

- equipment for keeping grazing sows including equipment for individual concentrate feeding when grazing,

- a range of grazing areas where pigs and cattle can be handled and graze together.

The facilities for cattle include:

- a loose housing system for dairy cows in which the individual voluntary feed intake can be recorded, 
- houses with deep litter for young animals in which the gas emission $\left(\mathrm{CO}_{2}, \mathrm{CH}_{4}\right.$, $\mathrm{NH}_{3}$ etc.) can be measured, mainly used for studying the effect of nutrition on the dynamics in deep litter produced and the corresponding loss.

With respect to experimental facilities for organic egg production, an experimental set-up has been established at Research Centre Foulum. Several small cottages with access to grazing areas for layers have been established and are used for mainly feeding and breeding experiments.

Complementary to studies carried out in the experimental units also studies are carried out on private farms, especially for topics that require many animals or where the specific conditions are important, i.e. in relation to grazing experiments. To support this purpose, agreements have been established with several organic livestock farmers in the area of pig, dairy and poultry production. On these study farms (more than 30 at the moment), all relevant information of the production is registered and evaluated including feed quality, feeding and production. In addition, some of the farms are equipped in a way that makes an experimental set-up possible.

It is our experience until now that the above mentioned facilities give good opportunities for studying the major topics in relation to nutrition in organic farming, where there is a strong interdependence between animal production and land use.

\section{NUTRITION OF CATTLE}

Cattle plays a major role in obtaining a high degree of closed nutrient cycles because of its ability to be fed on fibrous feed including legumes, which in turn are important elements in maintaining soil fertility and the potential to grow more concentrated feed for non-ruminants. In fact, it can be argued that the ruminants in relation to the development of organic farming in general have a particular "obligation" to complement nutritional requirements of other farm animals.

In the past, a lot of work has been done in the field of studying ruminants' digestion and utilization of fibrous feed. However, production systems have changed, higher genetic merit for milk yield in cows is present, and a main trend in more recent cattle nutrition research work has been focused on how to fulfil the higher nutritional requirements by other means than taking advantage of the unique feature of rumen fermentation. For the support of organic farming it is a main challenge for nutritionists to show new ways whercby appropriate diets can be composed by a variety of on-farm produced foodstuffs without deleterious effects on productivity, animal health and product quality.

For high producing animals such as dairy cattle it is in main focus how the nutritional requirements can be or should be met. It is well known that severe 
underfeeding impairs animal production and health, but on the other hand, strategies with moderate feeding of dairy cows in the first part of lactation have been implemented with success (Kristensen and Kristensen, 1998). A lower peak yield may help the animal to better tolerate certain nutritional imbalances. However, the information on an animal's adaptability to variation in nutrient intake is still very limited.

In a recent long-term experiment at the organic experimental station, a group of cows fed only clover grass during summer and clover grass silage in winter were compared to two groups of cows fed also supplementary energy and protein in concentrate (Sehested, 2000). Omitting supplementary feed resulted in a marked reduction in milk yield, a prolonged calving interval from 1 st to 2 nd lactation, and milk quality was impaired through an increased degree of lipolysis. Giving only small amounts of supplementary feed still far below standard nutritional requirements almost eliminated these differences compared to a standard feeding regimen, probably because of the ability of the cows to compensate through increased grass and clover grass silage intake. Detailed investigation on the grazing behaviour indicated that no supplemented cows selected more heavily for the easiest digestible part of the clover grass.

These results put focus on the possibilities to estimate voluntary grass intake by cows. Preliminary results with the alkane method showed promising results for total grass intake whereas the estimation of the botanical composition of the sward intake was less efficient. At the moment, the methods are under further development (Sehested, 2000).

A new project has been established partly on the organic experimental station and partly on private organic farms in which the influence of feeding organic feed (resulting in a reduced energy intake) on the health of the cows is investigated (DARCOF, 2001).

It is a challenge for future research in organic milk production to achieve:

- a much more detailed knowledge of cows' ability to adapt to variation in nutrient intake,

- a better understanding of the ability of grass to cover the nutritional requirements of high yielding cows including supply of vitamins and minerals,

- better tools for estimating feed intake in grazing situations,

- increased knowledge on basic grazing behaviour including selection of feeds and on means to influence grazing behaviour.

Also the feeding and feeding regimen of the young stock needs to be addressed. Due to the fact that many calves and heifers in organic farming are infected with coccidia or endoparasites, and since no prophylactic medical treatment is used in organic livestock production, the main challenges are probably more related to animal health than to nutrient intake as such. This, however, also represents chal- 
lenges to nutritionists. For instance, an element in natural helminth control can be the use of specific plants or herbs in animal feeding, in particular plants with a high content of condensed tannins (Thamsborg et al., 1999). Such plant species have been shown in some cases to reduce the parasite burden in young animals. The condensed tannins also affect the nitrogen metabolism reducing protein degradation in the rumen and can probably result in an increase in amino acid absorption in cattle grazing protein rich diets (Waghorn and Shelton, 1995). There is, however, a need to explore in more detail the consequences of feeding feeds with condensed tannins also in the very young animals.

At the organic experimental station, the infection with the nematode Ostertagia ostertagia in first-time grazing heifers was investigated in different grazing regimens. Heifers were grazing alone, in combination with sows or alternating with sows on the grazing area. The mixed grazing reduced the intensity of parasite infection evaluated on faecal egg counts and serum pepsinogen (Roepstorff et al., 2000 ). In addition, the grass quality in the mixed grazing system was improved, resulting in an increased daily gain of the heifers (Sehested et al., 2000). These results indicate that completely new systems may be interesting for the organic cattle production and that there is a need to explore these possibilities in more detail.

\section{NUTRITION OF PIGS}

According to Danish legislation for organic farming sows must have access to grass areas for a minimum of 150 days in the summer period (15th April to 1st November). Piglets may not be weaned from the sow until they are 7 weeks old compared to a minimum of 3 weeks in conventional production. Growing-finishing pigs of more than 8 weeks can be kept indoor provided they have free access to an open-air run and to roughage, fresh or dried fodder, or silage. The EU directive (EC 1804/1999) includes cereal straw as a roughage, whereas this is not the case in the Danish amendment.

The production results for sows in 4 large-scale organic pig production units (60-280 sow per unit) were inferior to the results obtained in indoor conventional herds due to higher weaning age and higher feed consumption (Lauritsen et al., 2000).

Forage and roughage do not only serve as a feed but also as rooting material and may have a beneficial effect on welfare and productivity of sows (Vestergaard, 1998). Rooting is a normal physiological behaviour in pigs. Unrung sows reduced vegetation cover to $10 \%$ within a month (Watson and Edwards, 1997) and may have a high ingestion of stones (Ferre et al., 2000). As legislation requires a wellcovered grass area in order to reduce leaching of $\mathrm{N}$ and $\mathrm{P}$ from the manure to the ground water, ringing of sows is allowed in Denmark. The extent to which pasture 
and roughage can contribute to the nutritional needs of the animals will depend on their voluntary intake and ability to utilise the dietary fibre components. Adult sows have a more developed intestinal system than younger pigs and are superior to digest fibrous diets (Fernández et al., 1986). A higher proportion of digestible energy was fermented in the hindgut of sows $(33 \%)$ when fed a wheat-bran diet compared to growing pigs (19\%), whereas the difference was smaller for the sugar beet pulp diet ( 31 vs $27 \%$ ), the intake of non-starch polysaccharides (NSP) being similar (Jørgensen et al., 2001). If high quality pasture is available, pregnant sows are able to cover $30-45 \%$ of daily energy intake (Sehested et al., 1999). In mixed grazing with sows and heifers, pregnant sows grazed up to approx. $4 \mathrm{~kg}$ DM daily in clover grass (Sehested et al., 2000). On the other hand lactating sows fed a whole-crop silage consisting of equal parts of wheat, barley and peas ad libitum and 100,85 or $70 \%$ concentrate were only partly able to compensate for the lower levels of concentrate by consumption of silage (Kongsted et al., 2000).

The energy and protein requirement of growing pigs are normally covered by concentrates. Until $200520 \%$ of the feed may be of conventional origin, then $100 \%$ must be of organic origin. This puts high restrictions on the availability of starchrich and protein-rich feed ingredients. Apparently, forage and roughage can only be utilized to a limited extent. The protein digestibility of various fibre rich diets for growing pigs was less than $45 \%$ (Carlson et al., 1999). Thus, protein and amino acid supply in organic pig production may really create a problem. In growing pigs fed on a concentrate with free access to clover grass and clover grass silage, roughage intake contributed with $4 \%$ of total net energy intake, and when concentrate was fed semi ad libitum this proportion increased to 5-6\% (Danielsen et al., 2000). The low concentrate feeding reduced daily gain in weight with $11-16 \%$, while FCR improved with $9-10 \%$. Percent lean meat in the carcass increased with $0.8-1.1$ units, but the meat was less tender, harder and had a more sour taste, while there was no significant effect on juiciness, meat flavour and off-flavour (Danielsen et al., 2000). High amounts of polyunsaturated fatty acids from oil seeds, oil cakes and grass of the n-6 (linoleic acid) or n-3 (linolenic acid) family may have deleterious effects on softness of the carcass and storage stability and quality of the meat (Jakobsen, 1999). The quality of organically produced meat is of high concern, especially the fatness and the palatability of the meat.

The requirements of vitamins and minerals of pigs under organic farming conditions are not known. The present breeds and crossbreeds used in organic production are fast growing, modern type pigs as used in conventional production. The Danish allowances for these nutrients are not taking the natural content of the feed ingredients into consideration.

Preliminary studies on pregnant sows showed that organically reared sows without addition of vitamins and minerals had higher blood concentrations of iron, zinc, vitamin $A, D$ and $\beta$-carotene and at least similar concentrations of other vita- 
mins and minerals as sows from a herd fed conventional diets (Christensen-Jakobsen and Sagredos, 1990). Organic pigs reared outdoor without dietary supply of vitamins and minerals had a similar gain in weight as those supplied with vitamins and minerals ( $750 \mathrm{vs} 805 \mathrm{~g} / \mathrm{day}, \mathrm{P}>0.05$ ), whereas those reared indoor without supply had a significantly lower growth rate $(688 \mathrm{vs} 811 \mathrm{~g} /$ day, $\mathrm{P}<0.05)$. The feed conversion efficiency was lower for the groups kept outdoor than indoor (Jakobsen and Jensen, 2000). Addition of vitamins and minerals to organic concentrates fed to the pigs had significant effect $(\mathrm{P}<0.01)$ on the concentrations in the ham muscle of vitamin $\mathrm{E}$, thiamin, pyridoxin, vitamin $\mathrm{B}_{12}$, zinc and selenium, whereas the effect of rearing conditions only improved the concentration of vitamin $B_{12}$ (Jakobsen et al., 2000). These studies indicate that the vitamins and minerals in the feed and soil, and synthesis from sunlight can be utilised to a higher degree than normally believed. Thus, there might be a potential in studying vitamin and mineral requirements and supply under organic farming conditions.

Recent investigations point to the dietary composition of NSP as a factor controlling parasite and bacterial infections. Diets leading to a high establishment with increasing egg excretion and worm number were characterised by high levels of insoluble dietary fibre and a relatively low digestibility, while diets providing readily degradable nutrients to the large intestine and with relatively high digestibility provided unfavourable conditions for the establishment of $O$. dentatum (Petkevicius et al., 2001). Most helminths are strictly host specific and therefore mixed grazing is well-known in helminth control (Thamsborg et al., 1999). Preliminary results of an experiment set up to elucidate whether mixed grazing can help controlling helminths in sows and heifers showed no effect on the $O$. dentatum infections of the sow, whereas the $O$. ostertagi infection level of susceptible first year grazing heifers was reduced (Roepstorff et al., 2000). Since the use of drugs in organic production is restricted there are obvious reasons to investigate the possibility of improving the resistance against infection with pathogens.

\section{NUTRITION OF POULTRY}

Although ducks and geese would fit better into organic farming than chickens of broiler type, the inclusion of ducks and geese into organic production in Denmark is limited. Therefore, in the following attention is mainly paid to chickens and laying hens.

Poultry must be reared under open-range conditions and cannot be kept in cages. This allows for scavenging except in wintertime, but it is not known how much energy and essential nutrients poultry is able to obtain from grass, plants, soil, worms, insects, sprouces, roots and droppings. Also, it is not known how much vitamin D may be synthesized from sunlight. For poultry the feed formula 
used in the fattening stage must contain at least $65 \%$ cereals and $80 \%$ must be of organic origin. Roughage, fresh or dried fodder or silage e.g. rootcrops, beet pellets, leafage, hay, or fruit and vegetable scraps must be added to the daily ration. The minimum age at slaughter shall be at least 81 days for chickens, and this requires slow growing breeds.

The nutrient requirements for poultry (NRC, 1994) are based on modern type, fast growing and high yielding breeds kept indoor in cages or on floor with little space to root in their droppings. The nutrient requirements of slow growing animals may be lower (NRC, 1994), but are not determined with the actual breeds and under organic farming conditions.

The digestibility and utilization of carbohydrates in poultry is highly dependent on the proportions of starch and dietary fibre. Maize and wheat are relatively rich in starch $(65-70 \%$ of dry matter (DM)) and relatively poor in dietary fibre (11-14\% of DM) and therefore highly digestible in poultry. However, maize becoming more commonly of GMO origin, may become limiting in organic farming, leaving wheat, barley, rye, oats and triticale as the main energy sources. The latter ones, however, contain higher proportions of NSP, $\beta$-glucan and lignin, which cannot be degraded by endogenous enzymes of the gastrointestinal tract, but may be fermented by the microbes of caeca and colon. Generally, the concentration of dietary fibre in the feed of poultry is not taken into consideration when estimating the energy value of the feed. However, it was recently estimated that dietary NSP might contribute to metabolizable energy (ME) with 7.8-8.6 kJ/g ingested NSP from a triticale based diet in young chickens, ducks and geese (Kirchgessner et al., 1999) and with 2.7$3.2 \mathrm{~kJ} / \mathrm{g}$ from a barley based diet in similar birds due to a lower digestibility of NSP (Jamroz et al., 2001). Expressed in relation to ME intake the NSP fermentation in the latter case contributed $3.5 \%$ which was also found for pea fibre, wheat bran or oat bran in broiler chickens (Jørgensen et al., 1996).

Laying hens with access to barley-pea whole-crop silage had a significantly lower egg production than hens with access to maize silage and carrots, but similar to the control group (Steenfeldt et al., 2001). The death rate was markedly reduced in the groups receiving roughage compared to the group receiving complete feed $(0.5-2.5 \%$ vs $15.3 \%)$. The digestibility of organic dry matter of barley-pea wholecrop silage given without complete feed was $71 \%$, for maize silage $51 \%$ and for carrots $50 \%$. Watery roughage may pose a problem as excess water is excreted in the droppings. This has a negative effect on the litter quality and impairs the welfare of the birds considering primarily footpad lesions due to increased ammonia evaporation.

In Denmark the organically grown protein sources are peas and rape seed, the latter to a limited extent. Blue lupin may be a future potent protein and energy source. Fish meal is a highly valuable protein source in diets of laying hens, but is not used for broilers due to risk of fishy off-flavour in the meat. 
An optimum supply of amino acids both in absolute amounts and relative to energy intake creates big problems in organic poultry production. The sulphur containing amino acids will be the limiting amino acids in a mainly wheat based diet. However, it was found that egg laying hens fed a mixture of wheat, barley, oats and peas with a methionine/cysteine content of $4.2 \mathrm{~g} / \mathrm{kg}$, which is $25 \%$ less than the recommended level, had a similar egg production and tendency to cannibalism as hens receiving extra methionine (Sørensen, 2000).

As for the vitamin supplementation the main problems may arise with vitamin A, $\mathrm{E}$ and $\mathrm{D}$. As for vitamin A organically farmed poultry will normally receive provitamin A in the diet. Beta-carotene, which is the most potent vitamin A source is generally believed to have the same vitamin A activity as in rats, i.e. 1667 IU vitamin A per $m g \beta$-carotene. However, in recent studies with broiler chickens it was shown that $1 \mathrm{mg}$ of $\beta$-carotene was equivalent only to $400 \mathrm{IU}$ vitamin A (Johannsen et al., 1998). The equivalence may be different for different plant material.

The possibility of reducing infectious diseases caused by microbes, nematodes and coccidia by dietary means is being investigated at the moment and may be a means to reduce the infection stress in poultry herds.

\section{PERSPECTIVES}

The production of animal foods may become a significant part of organic farming contributing to the income of the farmer and satisfying the demands from the consumers for a more steady provision of organically produced animal products on the markets, acceptable prices, and high quality and safety. Research and development is, however, highly needed within several aspects of animal production. Within nutrition knowledge about feed production, feed value, feeding concepts, feed utilization, nutrient requirements, dietary effects on animal health and welfare and product quality is vital for obtaining an efficient production without compromising the holistic idea of organic farm production and farm life. The great challenge for animal nutritionists is to provide this knowledge.

\section{REFERENCES}

Carlson D., Lærke H.N., Poulsen H.D., Jørgensen H., 1999. Roughages for growing pigs with emphasis on chemical composition, ingestion and faecal digestibility. Acta Agr. Scand, Sect. A, Anim. Sci. 49, 129-136

Christensen-Jakobsen K., Sagredos A., 1990. Status an Vitaminen, Mineralstoffen, Spurenelementen und Fettsäuren von ökologisch und konventionell gehaltenen Schweinen. Fat Sci. Technol. 92,437 
Danielsen V., Hansen L.L., Møller F., Bejerholm C., Nielsen S., 2000. Production results and sensory meat quality of pigs fed different amounts of concentrate and ad lib. clover-grass or clover grass silage. In: J.E. Hermansen, V. Lund, E. Thuen (Editors). Ecological Animal Husbandry in the Nordic Countries. DARCOF Report 2, pp. 79-86

DARCOF II, 2001. Increased production and closer relationships between organic and inherent qualities. An introduction to Danish research in organic farming 2000-2005. Danish Research Centre for Organic Farming (DARCOF), Foulum (Denmark), pp. 30

Fernández J.A., Jørgensen H., Just A., 1986. Comparative digestibility experiments with growing pigs and adult sows. Anim. Sci. 43, 127-132

Ferre M.G. Rivera, Edwards S.A., Mayes R.W., Riddoch I., Howell F.D. DeB, 2000. Grass utilisation by outdoor sows in different seasons measured by the n-alkane technique. In: J.E. Hermansen, V. Lund, E. Thuen (Editors). Ecological Animal Husbandry in the Nordic Countries. DARCOF Report 2, pp. 87.92

Foster C., Lampkin N., 1999. Organic Farming in Europe: Economics and Policy 3. Hohenheim, pp. 67

IFOAM, 2000. Basic Standards. Basel

Jamroz D., Jakobsen K., Wiliczkiewicz A., Bach Knudsen K.E., 2001. The energy value of nonstarch polysaccharides (NSP) for young broiler chickens, ducks and geese fed high amounts of barley. In: A. Chwalibog, K. Jakobsen (Editors). Energy Metabolism of Animals. EAAP Publication No. 103. Wageningen Pers, Wageningen, pp. 105 108

Jakobsen K., 1999. Dietary modifications of animal fats: status and future perspectives. Fett/Lipid $101,475-483$

Jakobsen K., Jensen S.K., 2000. Zur Vitamin- und Mineralstoffversorgung in der ökologischen Schweinemast. 1. Produktionsergebnisse sowie Nährstoff- und Fettsäurenzusammensetzung des Fleisches nach Verabreichung von ökologischem Futter mit oder ohne zusatz von Vitaminen und Mineralstoffen und mit oder ohne Zugang zu Gras im Vergleich zu konventioneller Haltung. Proc. Soc. Nutr. Physiol. 9, 79

Jakobsen K., Jensen S.K., Sagredos A.N., 2000. Zur Vitamin- und Mineralstoffversorgung in der ökologischen Schweinemast. 2. Konzentrationen an Vitaminen und Mineralstoffen im Fleisch nach Verabreichung von ökologischem Futter mit oder ohne Zusatz von Vitaminen und Mineralstoffen und mit oder ohne Zugang zu Gras im Vergleich zu konventioneller Haltung. Proc. Soc. Nutr. Physiol. 9, 83

Johannsen A.K.B., Jensen S.K., Jakobsen K., 1998. A note on vitamin A activity of $\beta$-carotene in broilers. Acta Agr. Scand., Sect. A., Anim. Sci. 48, 260-263

Jørgensen H., Zhao X.-Q., Bach Knudsen K.E., Eggun B.O., 1996. The influence of dietary fibre source and level on the development of the gastrointestinal tract, digestibility and energy metabolism in broiler chickens. Brit. J. Nutr. 75, 379-395

Jørgensen H., Bach Knudsen K.E., Theil P.K., 2001. Effect of dietary fibre on energy metabolism of growing pigs and pregnant sows. In: A. Chwalibog, K. Jakobsen (Editors). Energy Metabolism of Animals. EAAP Publication No. 103, Wageningen Pers, Wageningen, pp. 105-108

Kirchgessner M., Eder K., Müller H.L., Jamroz D., 1999. Zur energetischen Bewertung von Nichtstärke-Polysacchariden beim Geflügel. J. Anim. Physiol. Anim. Nutr. 81, 51-55

Kongsted A.G., Larchen J., Larsen V.Aa., 2000. Silage for outdoor lactating sows. In: J.E. Hermansen, V. Lund, E. Thuen (Editors). Ecological Animal Husbandry in the Nordic Countries. DARCOF Report 2, pp. 125-130

Kristensen T., Kristensen E.S., 1998. Analysis and simulation modelling of the production in Danish organic and conventional dairy herds. Livest. Prod. Sci. 54, 55-65 
Lauritsen H.B., Sørensen G.S., Larsen V.Aa., 2000. Organic pig production in Denmark. In: J.E. Hermansen, V. Lund, E. Thuen (Editors). Ecological Animal Husbandry in the Nordic Countries. DARCOF Report 2, pp. 113-118

Møller F., Olsen A., 1998. Forsøg med staldindretning og udearealer til økologiske slagtesvin. FØJORapport Nr. 1, 7.12

NRC, 1994. Nutrient Requirements of Poultry. 9th revised Editon. National Academy Press, Washington, DC

Petkevicius S., Bach Knudsen K.E., Nansen P., Murrell K.D., 2001. The effect of dictary carbohydrates with different digestibility on the populations of Oesophagostomum dentatum in the gastrointestinal tract of pigs. Parasitology (in press)

Roepstorff A., Monrad J., Schested J., Nansen P., 2000. Mixed grazing with sows and heifers parasitogical aspects. In: J.E. Hermansen, V. Lund and E. Thuen (Editors). Ecological Animal Husbandry in the Nordic Countries. DARCOF Report 2, pp. 41-44

Sehested J., 2000. Kombination af kveg og svin i økologiske husdyrproduktionssystemer. I: Slutrapporter fra forskningsprojekter i FØJO I. Danish Research Centre for Organic Farming. July 2000 , pp.161-170

Sehested J., Breinhild K.K., Søegaard K., Danielsen V., Fernández J.A., Kristensen V.F., 1999. Græsningssystemer og søers græsoptagelse - foreløbige resultater fra Rugballegaard. In: K. Jakobsen, V. Danielsen (Editors). Temamøde vedr. grovfoder og fiberrige fodermidler til svin. Intern Rapport Nr. 117, Danmarks JordbrugsForskning, pp. 14-20

Sehested J., Søegaard K., Danielsen V., Kristensen V.F., 2000. Mixed grazing with sows and heifers - effects on animal performance and pasture. In: J.E. Hermansen, V. Lund and E. Thuen (Editors). Ecological Animal Husbandry in the Nordic Countries. DARCOF Report 2, 35-40

Steenfeidt S., Engberg R.M. Kjær J.B., 2001. Roughage for laying hens. Internal Report, DIAS, pp. 8

Sørensen P., Kjær J.B., 2000. Analyse af det økologiske regelsat vedr. Husdyrsundhed og husdyrvelfærd. Fjerkræ. DARCOF, Febr. 2000, pp. 54-64

Thamsborg S.M., Roepstorff A., Larsen M., 1999. Integrated and biological control of parasites in organic and conventional production systems. Vet. Parasitol. 84, 169-186

Vestergaard E.MM,, 1998. The effect of dietary fibre on welfare and productivity of sows. Thesis. The Royal Veterinary and Agricultural University, Institute of Animal Husbandry and Animal Welfare, Copenhagen, pp. 104

Waghorn G.C., Shelton I.D., 1995. Effect of condensed tannins in Lotus corniculatus on the nutritive value of pasture for sheep. J. Agr. Sci. 128, 365-372

Watson C., Edwards S.A., 1997. Outdoor pig production: What are the environmental costs? In: Environmental and Food Sciences. Rescarch Report. SAC, pp. 12-14 


\section{STRESZCZENIE}

\section{Rolnictwo organiczne - wyzwanie dla nauki żywienia}

W pracy przedstawiono podsumowanie i stan badań dotyczących organicznej produkcji zwierzęcej w Danii, ze szczególnym uwzględnieniem bydła, świń i drobiu. Osiągnięcie w 2005 r. założonego celu, polegającego na pełnym pokryciu przez pasze organiczne potrzeb paszowych gospodarstw organicznych w UE, wymaga dużego stopnia zaopatrzenia w pasze własne. Ilość zboża i słomy jest ograniczona. W skład dziennej dawki pokarmowej muszą wejść pasze zielone i objętościowe. Zakaz stosowania GMO, syntetycznych aminokwasów i witamin, rozpuszczalników organicznych i preparatów leczniczych oraz wczesnego odsadzania, ogranicza rozwiązania alternatywne. Bardzo potrzebne są badania nad: 1. zapotrzebowaniem i pokryciem zapotrzebowania na energię, aminokwasy niezbędne, witaminy i związki mineralne zwierząt ras wolno-rosnących w warunkach gospodarstw organicznych, 2. opracowaniem systemów żywienia zwiększających odporność na infekcyjne choroby przewodu pokarmowego, 3. poprawą jakości produktu i opłacalności produkcji. Rozwiązanie tych problemów w sposób zgodny z całościową koncepcją rolnictwa organicznego i życia w gospodarstwie rolnym powinno być wyzwaniem dla naukowców zajmujących się żywieniem. 